\title{
Luiz Gama autor, leitor, editor: revisitando as Primeiras Trovas Burlescas de 1859 e 1861
}

LIGIA FONSECA FERREIRA ${ }^{I}$

Não borres um livro,
Tão belo e tão fino,
Não sejas pateta,
Sandeu e mofino.
Ciências e Letras
Não são para ti;
Pretinho da Costa
Não é gente aqui.
(Luiz Gama)

Negro sabido, negro atrevido (Ditado brasileiro)

$\mathrm{H}$ Á 160 anos, num Brasil escravocrata, formado em sua maioria por africanos e seus descendentes, surge em São Paulo a primeira edição das Primeiras Trovas Burlescas de Getulino (1859), de Luiz Gonzaga Pinto da Gama (BA 1830 - SP 1882). Dois anos depois, é publicada no Rio de Janeiro a segunda e última edição "correcta e augmentada". Em pleno período romântico, durante o qual o negro-escravo desponta como tema na poesia ou personagem no romance, as Primeiras Trovas Burlescas (PTB) inscrevem uma figura até então ausente da produção literária brasileira: o negro autor, que se enuncia e deseja ser visto enquanto tal ("negro sou"). O pseudônimo estampado na capa não é fortuito: "Getulino" deriva de "Getúlia”, território da África do Norte, entre as atuais Argélia e Mauritânia, habitada pelos "getulos” na Antiguidade. O autor assumia de cara sua origem africana.

Tal fato encerra ineditismo e transgressão. Gama nasceu livre em 21 de junho de 1830, filho da africana Luiza Mahin. O pai de origem portuguesa vende-o aos dez anos como escravo. Nessa condição chega a São Paulo, onde vive oito anos de escravidão. Para um indivíduo como ele, tornar-se homem de letras era algo improvável, numa época em que, escravizado ou não, negro não toma a palavra, não lê, não (se) escreve. A despeito disso, um ex-escravo atreve-se a "borrar" as páginas brancas de um livro e posicionar-se como observador crítico da sociedade brasileira no Segundo Império. 
A muitos escapou o efeito polifônico sob a ironia sutil e crua presente nos versos aqui colocados em epígrafe. Na realidade, o poeta faz ecoar discursos e crenças enraizadas entre os brancos, convencidos da incapacidade congênita dos negros para as atividades do espírito, cegos, portanto, às consequências mutiladoras da escravidão: "Na terra que rege o branco,/ Nos privam té de pensar!... Ao peso do cativeiro/ Perdemos razão e tino,/ Sofrendo barbaridades, Em nome do Ser Divino" (Gama, 2000, p.33). Ele estava ciente de encarnar um contraexemplo das teorias pseudocientíficas de há muito disseminadas no Ocidente sobre as desigualdades raciais. Prova de que os negros eram "naturalmente inferiores aos brancos", apoiava-se, segundo Hume, na constatação de não haver entre eles "nem artes, nem ciências" (Hume apud Honour, 1989, p.241). Desmentindo o filósofo iluminista, o tom ligeiro adotado por Gama, trinta anos antes da Abolição, expõe os preconceitos que atingem milhares de africanos e afrodescendentes sobre os quais pesa o estigma da cor e da escravidão, feridas abertas na pele de outros autores negros. Assim, com sua obra, o "Orfeu de Carapinha" adquire um passaporte para o mundo das "letras" e das "ciências". Sua voz antecipa Cruz e Sousa e Lima Barreto e abre o veio da literatura negra brasileira.

Revisitar as edições das PTB publicadas ainda em vida do autor nos dá a possibilidade de fruir seus textos e observar aspectos detectáveis apenas quando os textos passam por uma transformação, antes de tomarem a forma de um "objeto-livro" que apresenta a obra, garante sua presença no mundo, determina em princípio a maneira como e por quem será consumida, ou seja, sua recepção. Do final do século XIX ao início do século XXI, essas edições eram de difícil acesso, sobretudo a primeira, mais referida do que efetivamente consultada por alguns estudiosos de Luiz Gama. ${ }^{1}$ De alguns anos para cá, a situação inverte-se, graças à disponiblização de obras raras em acervos digitais. Porém, a leitura em suportes digital suscita algumas indagações: o que realmente se lê na tela? Um "texto"? Diante das opções, qual edição escolher? Que diferenças, textuais ou não textuais, aparecem de uma edição a outra? Como explicá-las? etc. É difícil responder essas perguntas, como é difícil colocar-se na mente do leitor confrontado com o luxo e os riscos da era digital. Lembremos que, sem demasiado aprofundar questões teóricas ou metodológicas, uma vez transformados em "livro", os textos acompanham-se de uma série de elementos verbais/discursivos (nome do autor, título, dedicatórias, prefácios, notas, epígrafes etc) e não verbais (formato, diagramação, ilustrações etc). Esses "paratextos editoriais" (Genette, 2009), aos quais nem sempre atentamos, podem influir na leitura, levantar questões que transcendem uma análise apenas centrada no texto. Uma obra em forma de livro, e particularmente quando distantes no tempo, precisa ainda ser apreciada em seu contexto mais amplo (histórico, social, político, literário, editorial). Mesmo sem manuscritos, é possível encontrar pistas sobre processos de criação subjacentes à produção editorial. Uma obra tampouco termina ao ser impressa e publicada, sobretudo se envolver reescrita e outras alterações textuais e para- 
textuais direcionadas a uma publicação posterior. As transformações da obra, do texto à materialidade do suporte, têm sido alvo de recentes reflexões e propostas metodológicas para uma "genética pós-editorial" (Mahrer, 2017).

À luz dessas reflexões, neste artigo pretende-se, pelo cotejo das duas primeiras edições das PTB, acompanhar nascimento, formação e evolução de um autor, desde o início envolvido na organização e produção editorial de seus livros, na realidade uma obra "dupla", por trazer ali poemas do amigo José Bonifácio, o moço (1827-1886). Considerando-se que um autor é antes de tudo um leitor, buscaremos identificar, por meio das epígrafes, leituras e modelos seguidos pelo novato poeta, em especial a obra do poeta português Faustino Xavier de Novais (1820-1869). Por fim, observaremos as mudanças e as etapas (textuais e não textuais) percorridas de uma edição a outra, buscando nos bastidores paratextuais a presença do autor, leitor e "editor" Luiz Gama, que se mostra sempre atento à recepção de sua obra em momentos e contextos diferentes, adivinhando as representações e expectativas desconfiadas acerca de um poeta atípico para os moldes sociais e intelectuais dos letrados de seu tempo.

Como se sabe, a filiação de Luiz Gama, mestiço biológico e cultural, sintetiza uma das matrizes nacionais de sua época: em seu corpo corre sangue da África e de Portugal, miscigenação àquela altura longe de ser celebrada. Será interessante notar como, em sua criação, o poeta luso-afro-brasileiro absorve, mescla, transforma e inclui e dá voz a elementos presentes em sua própria genealogia.

\section{Mas quem era Luiz Gama antes de 1859?}

\section{Em busca do saber e da liberdade, ou da liberdade de saber}

O estudo é o melhor entretenimento, e o livro o melhor amigo.

(Carta ao filho, 1870)

Em 1880, na célebre carta a Lúcio de Mendonça, um dos raros senão único relato de um ex-escravo brasileiro, Luiz Gama relembra a "amizade íntima" com Antonio Rodrigo do Prado Junior, estudante residente na casa de seu senhor, com o qual aprendera "as primeiras letras" em 1847 (Gama, 201la, p.202). Começava ali uma prodigiosa aventura para o adolescente de espírito vivo e curioso que, no ano seguinte, resgata "secretamente" a liberdade jurídica, sem suspeitar até onde chegaria no universo da leitura e da escrita. Nesse sentido, seu caso assemelha-se ao dos afro-americanos como Harriet Jacobs, Frederick Douglass e Williams Wells Brown, para os quais a conquista do saber acompanhou-se da conquista da liberdade. Instruíam-se para provar sua capacidade de expressar-se em linguagem rica de virtudes literárias, sem a qual não teriam desempenhado um papel histórico na vida política de seu país.

Luiz Gama, lembravam seus contemporâneos, tinha sempre um livro nas mãos. Desenvolveu não só o hábito como a paixão irrefreável pela leitura mesmo em situações adversas. Em 1854, depois de servir seis anos como soldado 
municipal, foi condenado por desacato a um insultuoso oficial a 39 dias de prisão onde "passava os dias lendo". Para ele, que jamais frequentou escolas, e acreditava que a "inteligência repele diplomas, como Deus repele a escravidão" (Gama, 2011b, p.136), o esforço precisava ser hercúleo para incluir-se ao restrito círculo de letrados no Brasil, verdadeira "ilha flutuante num oceano de analfabetos" (Fausto, 1994, p.184).

Aos 18 anos, o jovem praça teve um encontro determinante. Procurou pelo conselheiro Francisco Maria Furtado de Mendonça (1812-1890), chefe de polícia da capital, catedrático da Faculdade de Direito, para que esse lhe dispensasse os "primeiros lampejos da instrução primária". O poderoso e controverso figurão acolhe o jovem negro animado de uma "vontade inabalável de instruir-se", e por quase vinte anos foi seu "protetor", "amigo" e perfeito "mestre" (ibidem). O convívio era quase diário durante os anos em que serviu como ordenança e, em seguida, como amanuense no gabinete chefe de polícia a partir de 1856. Uma de suas tarefas é copiar documentos, e às vezes, em horas de folga do serviço militar, ele o faz para o escritório de um escrivão público. $\mathrm{O}$ trabalho na importante repartição de Furtado de Mendonça propicia ao expansivo amanuense travar conhecimento com “doutores" e familiarizar-se com o mundo e o saber jurídico. Ler e escrever entrava no âmago das atividades abraçadas pelo futuro jornalista e advogado Luiz Gama até o fim da vida. Mas naquele momento, importava ampliar conhecimentos. Furtado de Mendonça deve ter-lhe facilitado o acesso à Biblioteca da Faculdade de Direito, da qual era bibliotecário-chefe e, provavelmente, sua biblioteca pessoal (Menucci, 1938, p.55). Considerando-se o profundo conhecimento jurídico e a competência técnica futuramente demonstrados em processos e comentários jurídicos publicados na imprensa, Luiz Gama deve ter mergulhado na leitura da obra mais renomada de seu benfeitor - o Repertório Geral das Leis do Brasil (1808-1862).

Dos anos que precedem o encontro com Furtado de Mendonça até 1859, as leituras de Luiz Gama são diversas e não muito diferentes das realizadas pelos letrados e "doutores" de seu entorno: obras jurídicas, história, filosofia, literatura, especialmente poesia clássica e romântica, sátiras latinas e portuguesas etc. $\mathrm{O}$ perfil de Luiz Gama leitor se desenha num simples levantamento das referências presentes nas PTB de onde se pode depreender o âmbito das leituras, gostos e tendências ideológicas do poeta autodidata que deseja colocar-se à altura do nível cultural de seus leitores:

1) Escritores citados nas epígrafes: os portugueses Augusto Emílio Zaluar, Camões, Cândido Lusitano, Faustino Xavier de Novais, Nicolau Tolentino; o luso-brasileiro Gregório de Matos; os brasileiros Bernardo Guimarães, Junqueira Freire; o poeta latino Tíbulo e o francês Boileau.

2) Escritores e obras citadas nos poemas: Aretino, Ariosto, Buffon, Couvier, Dante, Homero, Lamartine, Paul de Kock, [Robert Joseph] Pothier, Schiller, [Torquato] Tasso; Alcorão e Arte de Furtar. 
3) Personagens da literatura citados nos poemas: Dom Quixote, Gulliver, Sancho Pança.

4) Outros (personagens históricos, filósofos, pintores, músicos: Aníbal, Bonaparte, Caravaggio, [Júlio] César, Columela, Constantino, Euclides, Mozart, Paganini, Plínio, Rossini, Savigny.

Não é puro acaso se todos os autores em epígrafes são de língua portuguesa. Ao contrário dos homens cultos de seu tempo, Luiz Gama não domina outros idiomas e não esconde isso. Ele não passara pelo ensino formal onde desde cedo aprendia-se " $a$ " língua estrangeira por excelência, o francês. Contemporâneos de Luiz Gama, Castro Alves, Rui Barbosa, Ferreira de Menezes e o mais convicto "afrancesado", Joaquim Nabuco, leem autores franceses no original. Luiz Gama os lê em traduções publicadas em Portugal ou no Brasil, mantendo-se de contínuo atualizado sobre as principais obras e correntes de pensamento produzidas na Europa. É o caso de Vida de Jesus (1863), de Ernest Renan, obra de repercussão mundial por sua abordagem racionalista e antirreligiosa do cristianismo, e que no Brasil marcou figuras tão díspares social, racial e ideologicamente como Dom Pedro II, Joaquim Nabuco e Luiz Gama, conforme já tratamos anteriormente (Ferreira, 2007).

As estrofes a seguir aludem, em pinceladas autobiográficas, à formação do principiante, preocupado (por real insegurança ou afetação) em ajustar, ou baixar, a expectativa dos seus cultos leitores. Em linguagem elaboradamente coloquial, o novo "autor" que, pretensamente não quer ser visto assim, falha discursivamente em alcançar seu intento, insiste no que o distingue cultural e linguisticamente de seu público, servindo-se de linguagem coloquial características de suas trovas :

Não tenho sabença,

Não campo de autor;

Apenas me conto

Por um falador.

Das línguas estranhas

Nem uma aprendi,

Em nosso idioma

Sou - Kikiriki. ${ }^{2}$

(Gama, 2000, p.88)

\section{José Bonifácio, o moço: amigo, abracadabra e santelmo}

Ao revisitar as PTB deparamos com dois autores, com duas obras em uma.

Em 1859, além de seus 23 poemas, Luiz Gama inclui três composições de José Bonifácio de Andrada e Silva, o moço (1827-1886), datadas de 1850: "Saudades do Escravo", "O tropeiro" e "Calabar". A primeira delas aparece em 
lugar de honra, em seguida ao "Prólogo", poema de abertura em que o autor apresenta a si e a sua obra (temas, gênero, valores morais, visão ideológica). A escolha da sequência, porém, não é fortuita. Não se indica o autor do texto, logo as primeiras linhas podem dar a impressão de tratar-se ali de versos saídos da lavra, da vida e da voz de Luiz Gama:

Escravo - não, não morri

Nos ferros da escravidão;

Lá nos palmares vivi,

Tenho livre o coração!

Nas minhas carnes rasgadas,

Nas faces ensanguentadas

Sinto as torturas de cá;

Deste corpo desgraçado

Meu espírito soltado

Não partiu - ficou-me lá!...

(Gama, 2000, p.162)

$\mathrm{O}$ asterisco ao lado do título remete à nota que por fim esclarece:

Esta bela produção foi-nos dada pelo seu ilustre autor o Exmo. Sr. Dr. José Bonifácio de Andrada e Silva; publicamo-la na frente de nosso obscuro volume para nos servir de Abracadabra, nos mares tempestuosos das censuras e nas hórridas ambages do sórdido egoísmo dos monopolistas. (Gama, 1859, p.12)

Homem de conviç̧ão liberal, antimonarquista e abolicionista, o sobrinho do Patriarca da Independência, cujo nome herdara, incluía-se decerto entre os amigos que incentivam Luiz Gama a publicar seus poemas, aliás nada ingênuos ("Não falo das flores/ Dos prados não falo/ [...] Nem das travessuras/ Do terno Cupido"), porém visando claramente a sociedade e a política imperial, o sistema escravocrata, o mundo jurídico, a hipocrisia racial etc. A função "cabalística" consistia em proteger o poeta negro e ex-escravo de eventuais represálias de quantos se sentissem visados pelo seu riso moralizador.

Mais do que valorizar seu próprio trabalho, o autor das PTB enxergou uma oportunidade de trazer ao conhecimento público os poemas escritos pelo amigo, intelectual de prestígio e poeta, havia mais de uma década. O ano 1850 representa um divisor de águas na história da escravidão. A promulgação da Lei Eusébio de Queirós, extinguindo o tráfico negreiro, acende a esperança nos antiescravistas. A questão produz impactos na produção literária brasileira, feita por homens igualmente envolvidos nos rumos políticos do país.

Nas PTB de 1861, edição "correcta e augmentada”, os 39 textos poéticos de Luiz Gama acompanham-se de dez poemas, reunidos no final do volume com o título "Poesias do Exm. Sr. Dr. José Bonifácio de Andrada e Silva". ${ }^{3}$ Um novo texto de apresentação - "A quem ler" justifica ao novo - e para Luiz Gama desconhecido - público da Corte a inserção dos poemas do amigo, cujo nome 
evoca sua alta estirpe, a família dos "Andradas". Num estilo mais elegante e com modéstia própria ao gênero e às circunstâncias, Gama confessa seu desejo e necessidade de contar com a proteção de um "padrinho", que o protegesse como "Santo Elmo", padroeiro dos marinheiros, nos mares nunca dantes navegados do meio literário da Corte. Ao informar que recebera de presente as poesias que agora "editava", ciente de sua importância do ponto de vista literário e político (tem-se ali o germe de uma poesia "engajada" na defesa do escravo, da abolição e do ideário liberal), Luiz Gama fala dos laços privilegiados, no plano pessoal e intelectual, que há tempos o uniam ao prestigioso poeta e político:

Estou por demais convencido do pouco que valem [as minhas], e por isso lancei mão das lindas poesias, que fazem parte deste volume, escritas pelo Exmo. Sr. Dr. José Bonifácio de Andrade e Silva, para servirem-me de santelmo nesta empresa temerária.

Estas belíssimas produções foram-me ofertadas pelo seu ilustre e modesto autor, sem a menor tenção de as ver impressas; e eu o acompanharia nesse propósito, a não ser coagido pela eminente necessidade, em que me vejo, de abrigar-me sob os auspícios de um valioso padrinho. (Gama, 1861, p.13)

A referência feita por um escritor novato a um "padrinho" literário, prática frequente na vida literária, deve ser bem compreendida. A despeito das diferenças sociais e raciais, os dois homens compartilhariam até o final da vida as mesmas ideias e afinidades políticas, éticas e estéticas. Uma relação respeitosa entre iguais. Não há subserviência do Negro ao Branco, mas sim gestos de cavalheiros. Herdeiros das Luzes, ambos abraçam e põem em prática os ideais Liberdade, Igualdade e Fraternidade.

Nascido em Bordéus, José Bonifácio fez direito em São Paulo de 1849 a 1853, na turma de Álvares de Azevedo. Seu livro de poemas líricos e épico-liricos, Rosas e Goivos (1849), é primeira obra literária publicada em São Paulo. De 1854 a 1855 leciona na faculdade paulista, antes de assumir por três anos um novo cargo na faculdade de direito de Recife. Retorna à capital paulista em 1858, onde assume a cadeira de direito criminal, especialidade abraçada na década pelo "advogado provisionado" e autodidata Luiz Gama. Embora não haja indicações precisas, é provável que os dois tenham se conhecido pouco antes da partida de José Bonifácio para o Nordeste (Faria, 1944, p.177). São jovens ainda -25 a 28 anos - para adivinhar o papel preponderante que viriam a desempenhar nos rumos das campanhas abolicionista e republicana. Logo, a amizade se trava bem antes de José Bonifácio encabeçar o movimento liberal de oposição liberal à monarquia e defender o fim da escravidão. Saudado como primus inter pares dos oradores brasileiros nos últimos trinta anos do Império, teve influência marcante junto a membros da última geração liberal, como seus ex-alunos Castro Alves, Rui Barbosa, Ferreira de Menezes e Joaquim Nabuco. Em São Paulo, o "devotado" Luiz Gama faz parte do pequeno círculo que frequentava a casa de José Bonifácio (ibidem, p.197). É intrigante, portanto, o fato de quase nunca 
haver menção, em notas biográficas como as do site da Academia Brasileira de Letras, à sua íntima amizade com o satirista negro que jocosamente tratava o amigo, loiro e de olhos azuis, de Mister José.

Difícil precisar quando Luiz Gama teria começado a redigir seus poemas. No entanto, é possível imaginar que só as submetera à apreciação de José Bonifácio depois de maio de 1858, quando esse retorna a São Paulo. Quanto a este último, os poemas ofertados a Luiz Gama para figurarem na primeira edição das PTB foram escritos em 1850 pelo segundoanista de direito. Templo da ideologia liberal, sob as arcadas surgiram as primeiras manifestações poéticas tratando do tema do escravo, anunciadoras da poesia condoreira. Luiz Gama não ignorava essas produções e as aproveitar na sua própria criação, apropriando-se de temas e construindo relações intertextuais. Seu poema "Cemitério de São Benedito" $(1859,1861)$ recebe como epígrafe a seguinte estrofe de "À sepultura de um escravo", na versão publicada primeira edição de Cantos da Solidão (1852) de Bernardo Guimarães: "Também do escravo a humilde sepultura / Um gemido merece de saudade:/ Ah caia sobre ela uma só lágrima / De gratidão ao menos" (Gama, 2000, p.153). O tema do escravo não é frequente nas PTB, e invalida qualquer tentativa de considerar sua poesia como "abolicionista". Porém, a imagem fixada no texto da epígrafe inspira ao poeta ex-escravo versos que o autorizariam a figurar entre os precursores daquela corrente que aparecerá, mais nitidamente, no final da década seguinte:

Aqui não se ergue altar ou trono d'ouro

Ao torpe mercador de carne humana.

Aqui se curva o filho respeitoso

Ante a lousa materna, e o pranto em fio

Cai-lhe dos olhos revelando mudo

A história do passado. Aqui nas sombras

Da funda escuridão do horror eterno,

Dos braços de uma cruz pende o mistério,

Faz-se o cetro bordão, andrajo a túnica,

Mendigo o rei, o potentado escravo!

(Gama, 2000, p. 154)

Com "Saudades do escravo", uma das primeiras composições românticas voltadas para o tema do escravo e da escravidão, coube a José Bonifácio inaugurar tal temática, dezoito anos antes da máxima expressão alcançada em $O s$ Escravos, por seu discípulo Castro Alves em $1868 .{ }^{4}$ É, aliás, nessa data que o poeta baiano, estudante em São Paulo, compõe o eloquente poema e o declama num meeting festivo, organizado pelos alunos de direito, para saudar o retorno à cidade e à docência do então deputado José Bonifácio, deposto do cargo, após a queda do governo liberal de Zacarias de Góes. Luiz Gama não deve ter faltado à homenagem ao amigo, emocionando-se como todos os presentes à declamação de seu conterrâneo. "Saudades do escravo" introduz a voz em primeira pessoa de um escravo dotado de humanidade. Tem-se a dicotomia explorada poste- 
riormente por outros autores: escravo do corpo e liberdade da alma; exílio na escravidão vivida no Brasil e sonho de evasão rumo à África imaginária. Nas PTB, tais evocações transparecem nos versos melancólicos de "Coleirinho", poema coroado por uma epígrafe de Tíbulo - “Assim o escravo agrilhoado canta” - sugestiva da metáfora escravo-pássaro:

Canta, canta Coleirinho,

Canta, canta, o mal quebranta;

Canta, afoga mágoa tanta

Nessa voz de dor partida

$[\ldots]$

Hoje triste já não trinas,

Como outrora nos palmares;

Hoje, escravo, nos solares

Não te embala a dúlia brisa.

O tema dos dois outros poemas épico-líricos de José Bonifácio incluídos na edição das PTB em 1859 evoca figuras históricas reais e traduz a ideologia daqueles brasileiros envolvidos na construção política e simbólica do país independente havia menos de quatro décadas, e que, ao contrário das demais nações americanas, se fundara e perpetuara a dinastia de sua antiga metrópole.

Em "Calabar", o poeta inclui-se entre os primeiros a reabilitar a imagem do oficial do mestiço (mameluco, ao que parece) tido pela historiografia luso-brasileira como "traidor": desertara as tropas coloniais para lutar contra os portugueses, no período da presença holandesa no século XVII. O personagem conspurcado por mais de dois séculos ${ }^{5}$ é elevado a personagem-símbolo contra a opressão do colonizador, independentemente de qual fosse:

Oh não vendeu-se, não! - ele era escravo

Do jugo português - quis a vingança,

Abriu sua alma às ambições de um bravo

E em nova escravidão bebeu a esp'rança!

$[\ldots]$

Calabar! Calabar! - foi a mentira

Que a maldição cuspiu em tua memória!

[...]

A quem traíste, herói? na vil poeira

Que juramento te prendia a fé?!

Escravo por escravo - essa bandeira

Foi de um soldado - lá ficou de pé!...

[...]

Oh deixai-o morrer ! — d'este martírio

Não alceis a calúnia ao grau da história !

O tema e as intenções políticas subjacentes devem ter agradado o "democrata" negro que jamais se admite como "súdito" do "Império brasileiro/ [que] Faz cousas de espantar o mundo inteiro" (Gama, 2000, p.18), ou seja, 
submeter-se a uma outra forma de escravidão, ele que, desde as PTB, não esconde seus pendores antimonarquistas.

Dentre as grandes personalidades internacionais da primeira metade do século, Giuseppe Garibaldi, o mítico “herói de dois mundos”, fascinava homens como Luiz Gama e José Bonifácio por sua participação em insurreições republicanas no Brasil. À altura em que José Bonifácio escreve o poema, o ex-marinheiro e militar italiano, atraído pelo socialismo de Saint-Simon, já havia deixado o Brasil, onde permanecera de 1835 a 1842 e tivera atuação decisiva na Guerra dos Farrapos e na criação da República Catarinense. De volta à Itália no final dos anos 1840, é celebrado como um dos principais artífices da Unificação Italiana. No último e mais longo poema publicado em 1859, o Andrada faz o retrato épico de um "herói da liberdade” não só de nações, mas de escravos:

Vai seu caminho, herói da liberdade,

Audaz guiando a marcial coorte !

[...]

Sabem-lhe a vida ardente - essa epopéia,

Com sangue escrita ao trom da artilharia,

Nas planícies - nos montes - sobre a areia,

Ou nos mares à voz da ventania!

$$
[\ldots]
$$

Oh! vinde de Itália, oh! bravos,

Vinde honrar essa coragem;

Vinde saudar na passagem

$\mathrm{O}$ vingador dos escravos!

(Gama, 2000, p.172 e 173)

Depois de presentear seus poemas a Luiz Gama sem intenção de publicá-los, José Bonifácio continuaria ofertando-lhe outros manuscritos, como a carta de 26 de abril de 1868 inicialmente destinada ao redator do periódico paulistano Democracia. A Guerra do Paraguai vivia momentos críticos, uma grande crise política prepara um golpe conservador. No documento, o então deputado externava seu ceticismo quanto às infrutíferas certezas do exército brasileiro antes da batalha de Humaitá. Vislumbrava o fracasso e confessava sua "consciência revoltada" diante de um país arrastado por uma política de destruição e fadado ao "ridículo aos olhos da História". Em 1880, Luiz Gama comunica o "precioso documento literário e político" ao editor José Maria Lisboa do Almanaque Literário de São Paulo para o ano de 1881 no intuito de divulgá-lo aos seus leitores (Gama, 1880, p.201-5).

Quem se sentisse tentado a aprofundar-se no estudo das relações existentes entre Luiz Gama e José Bonifácio, o moço, encontraria, a meu ver, um grão de semelhança com o sentimento resumido por Montaigne na célebre frase a respeito de sua virtuosa amizade com La Boétie - "porque era ele, porque era eu” - em que cada qual mantém sua singularidade no equilíbrio entre reciprocidade e complementaridade. 
Pelo exposto acima, não seria exagero afirmar que as primeiras edições das PTB, preparadas por seu autor, dão outra contribuição fundamental para história literária e editorial no Brasil. A publicação de duas obras em um só livro, nas duas edições do século XIX (em algumas edições póstumas no século XX, os poemas de Bonifácio serão retirados), tem, por parte de seu principal autor, Luiz Gama, intenções claras, de natureza política e literária. O "projeto editorial" proposto aos leitores não faria sentido se as obras fossem desmembradas, pois em muitos níveis se complementam, e não se trata aqui apenas dos respectivos "textos". O livro de Gama talvez não tivesse existido sem o estímulo de Bonifácio. Os poemas deste poderiam ter se perdido, ser desconhecidos dos leitores da época e atuais, não fosse a decisão de Luiz Gama de publicá-los como parte do seu. Graças a iniciativas de ambas as partes, garantiu-se "materialidade" e "presença no mundo" aos dois objetos-livros das distintas edições das PTB, cuja divulgação ao longo do século XX foi vítima de revezes do tempo e da memória. ${ }^{6}$

\section{De uma edição à outra: percursos}

Em 1859, sai a primeira edição das PTB, contendo 22 poemas de Luiz Gama e três poemas de José Bonifácio, o moço.

No poema de abertura ("Prólogo"), o novato autor expõe sua (falsamente tímida) postura, intenções, e natureza dos trôpegos versos de um livro que não promete a qualidade e perfeição de inigualáveis vates, mas sim o riso farto da sátira:

No meu cantinho

Encolhidinho, Mansinho e quedo,

Banindo o medo

Do torpe mundo,

Tão furibundo,

Em fria prosa

Fastidiosa -

O que estou vendo

Vou descrevendo.

Se de um quadrado

Fizer um ovo,

Nisto dou provas

De escritor novo.

Sobre as abas sentado do Parnaso, Pois que subir não pude ao alto cume, Qual pobre, de um Mosteiro à Portaria, De trovas fabriquei este volume.

Vazias de saber, e de prosápia, Não tratam de Ariosto ou Lamartine Nem recendem as doces ambrosias De Lamiras famoso ou Aritine. 
São rimas de tarelo, atropeladas,

Sem metro, sem cadência e sem bitola

Que formam no papel um ziguezague,

Como os passos de rengo manquitola.

(Gama, 2000, p.7-8)

A originalidade das PTB não se limita à hipotética habilidade do poeta em manipular linhas geométricas, mas ao caráter sui generis da obra dentro da produção literária brasileira e, particularmente, paulista.

No final dos anos 1850, a vida intelectual marca-se ainda fortemente pela mística indianista a alimentar projetos de fundação de uma literatura genuinamente brasileira quando surge o grande romance nacional - O Guarani (1857), de José de Alencar. Porém, outras manifestações então menos visíveis, por acontecer longe dos holofotes da Corte, vêm sendo hoje trazidas à tona, como a emergência da autoria negra. No Maranhão, coincide com as PTB a publicação de Úrsula, tido como primeiro romance abolicionista brasileiro, da escritora afrodescendente Maria Firmina dos Reis, É também de 1859, em gênero e estilo totalmente opostos às PTB, o volume Primaveras, obra única de Casimiro de Abreu, poeta menor alçado a estatura maior, com direito a vaga na Academia Brasileira da Letras, graças ao sucesso alcançado com poesias em linguagem simples, dedicadas à saudade da infância, a natureza, o sentimentalismo religioso, o patriotismo difuso etc.

Além de inaugurar a carreira de um autor atípico, a primeira edição das PTB evoca as condições da produção editorial em São Paulo da época. Não há comparação com a capital do Império, cuja hegemonia no setor é incontestável até 1880. A atividade editorial paulistana coincide com a criação dos cursos jurídicos em 1827, sem resultados expressivos até o início dos anos 1850. Rosas e Goivos (1849), de José Bonifácio, o moço é a primeira obra literária publicada em São Paulo. Três anos depois, vêm a lume os Cantos da Solidão, de Bernardo Guimarães, obra da qual Luiz Gama extrai, como já mencionado, uma das epígrafes das PTB. Ambos os livros foram impressos na Tipografia Liberal de Joaquim Roberto de Azevedo Marques, proprietário do Correio Paulistano, para o qual Luiz Gama escreveria regularmente dos anos 1860 ao final da vida, e com quem manteve estreita convivência enquanto "irmãos" na loja maçônica América. Esses três nomes e o do tipógrafo Antonio Louzada Antunes refletem o envolvimento do "Orfeu de Carapinha" com o meio literário e editorial de uma cidade considerada por viajantes estrangeiros, em meados dos anos 1850, como a "mais intelectual", a "menos comercial" e com forte "cultura liberal" (Hallewell, 2005, p.300-1). À época, existem três tipografias e o amanuense da Secretaria de Polícia confiará seu livro à mais ativa delas, a Tipografia Dois de Dezembro, propriedade de Louzada Antunes. Situada nas dependências do Palácio do Governo, onde trabalhava Luiz Gama, a empresa imprime atos oficiais, obras de natureza histórica ou jurídica, revistas acadêmicas como os Ensaios 
Literários do Ateneu. O tipógrafo e o poeta se reencontrarão, dez anos depois, "irmãos" da mesma loja maçônica (Ferreira, 2001, p.143).

O trabalho das tipografias paulistas, no entanto, deixava a desejar e a impressão, do ponto de vista financeiro e editorial, corria por conta do autor. Luiz Gama teria arcado sozinho com as despesas para a publicação de seu livro? Recebera ajuda de amigos ou de seu poderoso "protetor", o chefe da polícia Furtado de Mendonça? Seja como for, é provável que a primeira edição das Primeiras Trovas Burlescas não tenha ultrapassado mais de duzentos exemplares. Tratava-se de uma obra de um principiante de parcos recursos, dirigida sobretudo aos leitores paulistanos, público em sua maioria masculino, formado por letrados, acadêmicos e doutores direta ou indiretamente ligados à Faculdade de Direito e a órgãos públicos como a repartição em que trabalhava o jovem autor.

Não se sabe como ou por que Luiz Gama teve a ideia dessa publicação. Quando começou a escrever os seus? Quando os terminou? Com exceção de um único, os textos não são datados. É certo, porém, que a "Musa de Guiné", invocada em "Lá vai verso!" inspira-o até bem próximo dos preparativos da edição: o poema-dedicatória "No álbum do Sr. Capitão João Soares" é datado de "Janeiro de 1859". No livro não há menção da data de término da impressão, mas possivelmente tenha ocorrido no final do ano. Em 7 de fevereiro de 1860, a Revista Comercial de Santos comenta que "acaba de sair [...] em uma das tipografias da capital uma coleção de lindíssimas poesias chistosas, sob o título de Primeiras Trovas Burlescas de Getulino [...]” (Ferreira, 2001, p.211).

Outras pistas acerca do período de redação dos poemas são dadas por importante elemento paratextual - as epígrafes -, em geral negligenciadas por quantos se interessam pelos escritos poéticos de Luiz Gama, focando exclusivamente o "texto" dos poemas. A epígrafe, porém, como lembra Genette, não é mero ornamento. Sua presença indica a "época, o gênero ou a tendência de um escrito" e a época romântica fez grande uso desse modo particular de intertextualidade, "imbuída de uma dimensão 'polifônica', pois o texto do epigrafador faz ecoar a voz do autor epigrafado" (Genette, 2009, p.141).

Chama, pois, a atenção que, das dezoito epígrafes encontradas nas PTB, onze, incluindo a capa, remetem a Faustino Xavier de Novais (1820-1869). Poeta satírico português de boa fama em seu país, onde era visto como continuador de Nicolau Tolentino, viveu no Rio de Janeiro de 1858 a 1869, ligando-se ao círculo de Machado de Assis, seu cunhado. Sua popularidade era imensa nessas plagas. Termômetro disso, os oito mil exemplares do último livro lançado em Portugal terem sido consumidos quase integralmente no Brasil (Cabral, 1988, p.452).

Gama colhe suas citações em duas obras - Poesias (1856) e Novas poesias (1858) (Quadro 1). A influência da visão do mundo e dos procedimentos poéticos característicos do poeta portuense é inegável em Luiz Gama, aliás bastante 
atraído pela literatura portuguesa e sua abertura para a sátira, gênero cultivado de forma constante em Portugal desde a Idade Média. Em outras epígrafes das PTB, há citação de Camões ("A cativa”), de Nicolau Tolentino ("Os glutões”), Augusto Emílio Zaluar ("Quem sou eu”).

Quem o fez descobrir o poeta portuense com o qual de pronto se identifica? Teria lido suas obras nas bibliotecas de Furtado de Mendonça? Na impossiblidade de responder essas perguntas, têm-se ao menos elementos para supor que as suas "grosseiras produções d'inculta mente/ em horas de pachorra construídas" foram redigidas entre 1856 e 1859. Aludindo ao seu processo criativo, em poema que traz epígrafe de Faustino ("O álbum do Sr. Capitão João Soares"), o enunciador evoca os desafios enfrentados, antes de ceder ao esforço inútil de transformar em texto aceitável suas ideias "delirantes":

Se, por desenfado,

No meu triste lar,

Com penas e tinta

Me ponho a brincar ;

Se acaso uma ideia,

Que vaga perdida,

Da minha cachola

Faz sua guarida ;

Se astuto demônio,

Finório birbante,

Soprando na testa,

Me faz delirante ;

E se dominado

Por esse rabino,

Algumas sandices

Escrevo, sem tino,

Depois refletindo

No fofo aranzel,

Em mil pedacinhos

Eu faço o papel.

(Gama, 2000, p.88-9)

A Luiz Gama não passou despercebido o uso abundante de epígrafes nos próprios poemas de Faustino (Quadro 1), e a intenção de aprender e reproduzir o mesmo procedimento deve ter-lhe exigido um esforço de análise, a fim de compreender-lhes a origem, a função, a relação intertextual com o texto epigrafado etc. A comparação de alguns aspectos comuns nas obras dos dois poetas é reveladora. Vejam-se, por exemplo, os título respectivos de alguns poemas de Novais e de seu discípulo brasileiro: 


$\begin{array}{ll}\text { Não é prólogo" } & \text { "Prólogo" } \\ \text { “As carapuças" } & \text { "Sortimento de gorras para } \\ & \text { a gente do grande tom" } \\ \text { "No álbum do meu íntimo } & \text { "No álbum do meu amigo } \\ \text { amigo Carlos N. P. Gandra" } & \text { J. A. Silva Sobral” } \\ \text { "A um aspirante a poeta" } & \text { "A um vate enciclopédico" } \\ \text { "Que mundo este !" } & \text { "Que mundo é este ?” }\end{array}$

Faustino - e no seu bojo toda uma tradição portuguesa - foi claramente uma das principais leituras na fase anterior à elaboração dos textos das PTB, e modelo no qual "Getulino" mais se espelhou, imitando, “devorando", transformando, quando não subvertendo, com tempero africano, o que era apenas matriz "luso-brasileira", como aponta a afiada análise de "Lá vai verso" (Marques, 2018, p.18-21):

Ó Musa de Guiné, cor de azeviche,

[...]

Empresta-me o cabaço d'urucungo,

Ensina-me a brandir tua marimba,

Inspira-me a ciência da candimba,

Às vias me conduz d'alta grandeza.

[...]

Quero que o mundo me encarando veja,

Um retumbante Orfeu de carapinha,

Que a Lira desprezando, por mesquinha,

Ao som decanta de Marimba augusta.

(Gama, 2000, p.10-11)

Epígrafes e títulos aqui brevemente abordados sinalizam o potencial investigativo das relações intertextuais entre os dois autores ainda por fazer. Luiz Gama identificou-se, como Machado, com a "graça, a irreverência e o desassombro da sátira de Faustino [...], com suas raízes fundas na tradição portuguesa" (Guimarães, 2012, p.121). Para aprender e compreender-lhes as estruturas, Luiz Gama mergulhou profundamente naquelas obras, razão pela qual arrisco-me a dizer que ele mereceria ser destacado como um dos primeiros leitores e admiradores brasileiros do sátiro portuense.

Outro paratexto nos informa que, depois de redigir seus textos, ele se ocupa pessoalmente da edição/impressão para transformá-los em livro e não esconde dos leitores as dificuldades daquela tarefa realizada pela primeira vez. Os exemplares não foram impressos ao mesmo tempo, e ainda foi possível a Gama substituir palavras, corrigir grafia e alterar métrica. Nas “erratas” em folha avulsa 
incluída nos exemplares consultados, assinalam-se algumas gralhas: "sentilantes" no lugar de "scintilantes", esclarecendo que esse erro escapara em "alguns exemplares"; à "página 55 , verso 5 , sucia, leia-se - chusma"; à página 57 , verso 15, o mar velho, leia-se - o Mar Vermelho" etc. O autor-editor neófito descobria os mistérios da arte tipográfica e solicita modestamente a compreensão dos leitores, uma vez que

Outros muito erros ter-nos-ão escapado, apesar do cuidado que pusemos na revisão das provas; deles pedimos desculpa aos benévolos leitores.

Alguns pequenos defeitos de metrificação existem, que não corrigimos por insignificantes, e justificáveis, atenta a nossa condição de principiante, e carência de conhecimentos. (Gama, 1859)

Apesar das imperfeições acima, os esforços de Getulino serão coroados de sucesso. Se a recepção de sua obra o preocupara em virtude de sua condição de "escritor novo", seus receios se revelariam inúteis. Pouco tempo depois de serem lançadas, em fevereiro 1860 a Revista Comercial de Santos recomendava aos seus leitores aquelas trovas "espirituosas", marcadas pela sua "originalidade humorística" e pelo "raro talento do autor", portanto "dignas de ocupar um lugar meritório na série de produções da literatura brasileira".

*

Incentivado pela boa crítica e por amigos, Gama ousará ir mais longe e publica, em menos de dois anos, a segunda edição das PTB no Rio de Janeiro, centro nervoso e teatro das letras e da política no Brasil, onde se concentra o maior número de leitores e de pessoas influentes do país. Reeditar na corte uma obra antes publicada numa cidade até então culturalmente inexpressiva como São Paulo é uma verdadeira consagração.

Luiz Gama foi à corte para acompanhar as etapas finais da confecção do livro, aproveitando a viagem para buscar pela última vez sua mãe, Luiza Mahin, da qual fora brutalmente separado havia 24 anos (Gama, $201 \mathrm{la}$, p.200). Na advertência ao leitor ("A quem ler"), datada de 28 de maio de 1861, Luiz Gama informa ter dado a prelo as provas de sua obra acompanhadas do ideal a ser impresso na Tipografia de Pinheiro \& Cia, estabelecimento modesto onde serão publicados alguns romances de José de Alencar nos anos 1860. Novamente, não se sabe por que intermédio Luiz Gama entrara em contato com esse profissional. O resultado da edição e do objeto-livro é incomparavelmente superior à de 1859, graças à habilidade dos tipógrafos cariocas. Aliás, as duas experiências em São Paulo e no Rio - despertariam o interesse de Luiz Gama pela tipografia, o que lhe seria muito útil no futuro. Quando perde seu cargo na prefeitura de polícia em 1868, ele exercerá o ofício de "aprendiz-compositor" na tipografia do jornal O Ipiranga (ibidem, p.203).

A edição "correcta e augmentada", de 252 páginas, compõe-se de 39 poemas, sendo vinte composições novas, ou seja, quase o dobro em relação à an- 
teiror, da qual, por alguma razão (conselhos de amigos?), foram suprimidos três poemas que permaneceram praticamente desconhecidos, de 1861 ao final do século XX: "A Guarda Nacional", "Carta do Vate Muriçoca a seu prezado amigo Zebedeu" e "O fósforo" (Quadro 2). Quanto aos poemas de José Bonifácio, o moço, reunidos no final do volume, o aumento de três para dez também foi significativo, conforme se viu acima. Gama manteve o título da obra e, na capa, a mesma epígrafe de Faustino X. de Novais, novamente o autor mais epigrafado nas novas composições.

O livro de 1861 é dedicado ao "protetor e amigo" Furtado de Mendonça, como "mesquinha prova de profundo reconhecimento", pela iniciação cultural, literária e cívica que lhe devia, e assina "o seu humilde servo L. G. Pinto da Gama". A atitude causa estranheza, pela quando se conhecem a personalidade e altivez do futuro abolicionista. É preciso, no entanto, relembrar o papel fundamental, para não dizer estratégico, do homenageado na formação e inserção social, profissional e cultural de Luiz Gama até aquele momento. Entrevê-se nessa dedicatória a implícita etiqueta que regia relações mais próximas entre negros e brancos, sobretudo quando, ao dispensar favores, esses esperam lealdade e submissão. Mas não nos enganemos: Luiz Gama compreendeu anos mais tarde que "os protetores são os piores tiranos", como dirá Lima Barreto. Em 1869, já conhecido ativista e advogado, ele rompe publicamente com seu ex-"protetor", por tê-lo coagido a abandonar as "causa de liberdade" (Ferreira, 2010, p.23840). Para Luiz Gama, gratidão tinha limites, éticos sobretudo. Recusou-se a devolvê-la com subserviência, da mesma forma que não seria subserviente aos seus modelos literários.

Sob vários aspectos, o livro de 1861 reflete tanto o amadurecimento poético do autor como o labor exigido pela reescrita dos antigos e redação de novos poemas. Além das correções ortográficas, Gama modifica alguns títulos e retoca os textos a fim de aprimorar a métrica, prosódia ou expressividade. A $17^{\text {a }}$ estrofe de "O velho namorado" algumas alterações:

\begin{tabular}{|l|l|}
\hline 1859 & 1861 \\
\hline$\underline{\text { Abrem-se as portas, }}$ & $\underline{\text { Escancr'am-se as portas, }}$ \\
$\underline{\underline{\text { Entra } 0 \text { velhote } ;}}$ & $\underline{\text { Lá entra o velhote, }}$ \\
$\underline{\text { Qual de azeitonas }}$, & $\underline{\text { De negra azeitona }}$ \\
\hline$\underline{\text { Redondo ancorote }}$ \\
\hline
\end{tabular}

No novo contexto, a esperança de Luiz Gama em atingir novos leitores, na corte e em outras províncias, faz supor que a tiragem de seu livro superasse a anterior: 400, 500 exemplares? Difícil saber. Porém, dentre seus eventuais leitores na corte, certamente teria agradado ao satirista autodidata, agora não mais tão principiante, saber que um exemplar das PTB chegara às mãos de Faustino, àquela altura estabelecido na cidade e em alguns círculos intelectuais. 


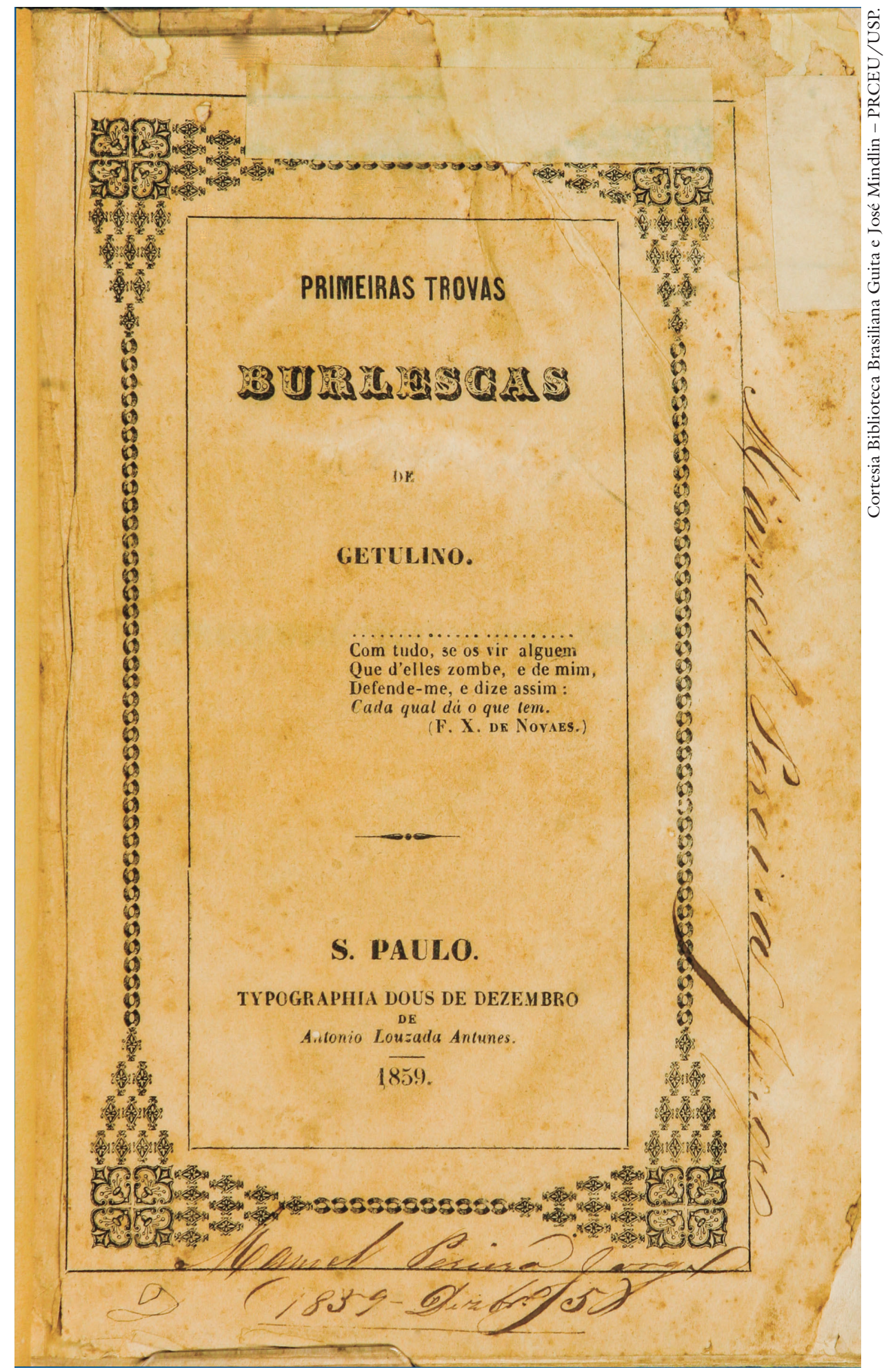

Capa da primeira edição das Primeiras Trovas Burlescas de Getulino (São Paulo, 1859, 126p., 21x14cm). 


\section{PRIMEIRAS \\ THOVAS BURLESGAS}

DE

GETERTE

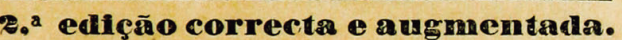

Comtudo se os vir alguem

Que d'elles zombe, e de mim,

Defende-me, e dize assim:

Cada qual dá o que tem.

F. X. DE Novaes.

arreorn

RIO DI A NEIRO.

TYP. DE PINHEIRO \& $C^{\circ}$, RITA DO GANO N. 165.

Jes: 8

Capa da segunda edição "correcta e augmentada" das Primeiras Trovas Burlescas de Getulino (Rio de Janeiro, 1861, 232p., 17x11 cm). 
A partir de novembro de 1869, Luiz Gama vive momento turbulento no plano profissional e político, situação que, paradoxalmente, traria benefícios à sua popularidade em São Paulo. Nas páginas de vários jornais, leem-se anúncios como este, publicado no Correio Paulistano de $1^{\circ}$ de março de 1870:

"Poesias joviais e satíricas"

por Luiz Gama

Os últimos exemplares da 2a. edição enriquecidas com belíssimos cânticos do exmo. conselheiro José Bonifácio.

Vende-se nesta tipografia a $2 \$ 000 .^{8}$

Curioso notar, colado a esse anúncio, dois outros em que Luiz Gama oferece seus serviços profissionais como advolgado criminal, de onde retira seu sustento, e seus préstimos como advogado para tratar "causas da liberdade" na capital ou fora dela, "tudo sem retribuição alguma". Dez anos depois de lançar as PTB, as identidades e o ethos de Luiz Gama se ampliam: além do poeta e autor, o advogado e o ativista.

Depois 1861, Luiz Gama não abraçou outros projetos poéticos ou literários. No entanto, a escrita faria parte do cotidiano do advogado e jornalista. Publicaria alguns poemas na imprensa entre 1865 e 1876 (Gama, 2000, p.289). Outras tarefas o aguardavam aquele comunicador exímio que usou eficazmente de todas os meios de sua época para divulgar e defender suas ideias. Cerca de vinte anos mais tarde, o legendário abolicionista refere em duas palavras, minimizando-lhe a importância, sua incomum passagem pela literatura: "Fiz versos" (Gama, 201la, p.203).

Ainda que reduzida - 51 poemas, incluindo aqueles publicados na imprensa entre 1864 e 1876 (Gama, 2000, p.220-9) -, a produção poética de Luiz Gama se distingue por seu ecletismo, graças à variedade de gêneros (sátira política e de costumes, paródias heróico-cômicas, bestialógico ou non-sens, poemas líricos), de estilos (influências clássicas e romantismo), de temas (o mundo às avessas, a corrupção dos políticos, a hipocrisia racial da sociedade imperial, $\mathrm{o}$ preconceito racial, o anticlericalismo, a frivolidade feminina, a caricatura de tipos sociais, a inépcia dos magistrados, o amor, o escravo), de linguagens e referências culturais (erudito $X$ popular ou coloquial, africanismos).

Ainda que tenha afirmado o contrário com a ironia habitual em um de seus poemas ("Faço versos, não sou vate"), uma musa original havia inspirado Luiz Gama. Sua obra correu o risco de apagar-se no tempo, motivo que nos instiga a revisitá-la em sua companhia. E a (re)descobri-lo - autor, leitor, editor - nos bastidores paratextuais dos surpreendentes objetos-livros que diligente e orgulhosamente em vida preparou. 


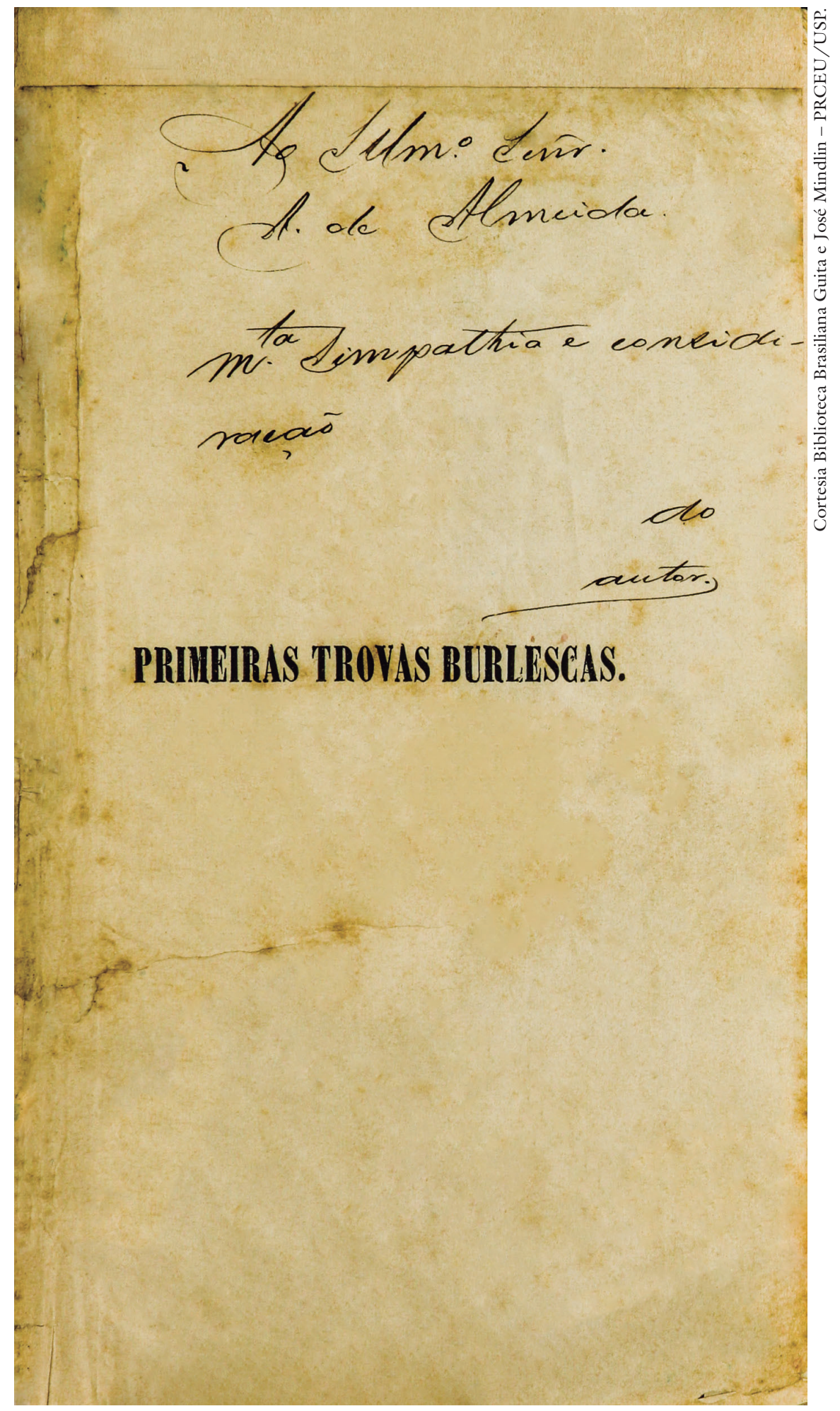

Dedicatória manuscrita de Luiz Gama: "Ao Illmo. Snr. A. de Almeida./ mta sympathia e consideração/ do autor". Primeiras Trovas Burlescas de Getulino (1861). 
Notas

1 Segundo nosso levantamento, apenas duas instituições possuem as duas edições das PTB: Biblioteca do Instituto de Estudos Brasileiros e Biblioteca Brasiliana Mindlin (inclusive acervo digital). Na Biblioteca Mário de Andrade e a Biblioteca Nacional existe apenas a edição de 1861. As obras não foram localizadas em outros acervos.

2 Kikiriki = onomatopeia do canto do galo, ainda hoje corrente em espanhol. O termo provavelmente circulava à época no Brasil. Entre 1853 e 1854, o Periódico dos Pobres (RJ) publica, em alguns números, paródias com título “Carta do Barão [ou Visconde] de Kikiriki”.

3 Além dos poemas anteriores, foram incluídos: "A Rodrigues dos Santos”, "Enlevo", “A Garibaldi", “Teu nome", "Prometeu”, "Saudade" e "Olinda".

4 Em geral atribui-se a paternidade da poesia abolicionista a Castro Alves. Sobre o papel precursor de José Bonifácio e de outros nomes, ver Sayers (1958, p.195-8).

5 Um ano antes da publicação das PTB, o baiano Agrário Meneses escreve o drama Calabar, inspirado na peça Toussaint Louverture de Lamartine, encenada em Paris em 1850. Em 1872, Elpídio Pereira escreve a ópera Calabar, com livreto em francês (Sayers, 1958 , p.262-8). Tais obras parecem ter servido de fonte para a peça "Calabar ou o elogio da traição", de Chico Buarque e Ruy Guerra.

6 Cem anos depois de lançada a segunda edição das PTB, em 1962, Bosi e Scalzo organizam o volume Poesias de José Bonifácio, o moço (Silva, 1962). Tivemos a oportunidade de publicar Primeiras Trovas Burlescas \& outros poemas de Luiz Gama (Gama, 2000). Além do cotejo, até então inexistente, das edições de 1859 e 1861, foram incluídos os poemas de Luiz Gama publicados na imprensa e os poemas de José Bonifácio, o moço (ver referências).

7 Esses poemas foram incluídos na edição de Primeiras Trovas Burlescas e outros poemas (Gama, 2000). As alterações de uma edição à outra foram indicadas em notas de rodapé.

$8 \mathrm{Um}$ acaso ou coincidência notados nesse anúncio revela uma vez mais a importância das referências portuguesas na cultura literária de Luiz Gama: Poesias joviais e satíricas é o título de uma obra do poeta português Antonio Lobo Carvalho, publicada em 1852 em Lisboa.

\section{Referências}

CABRAL, A. Dicionário de Camilo Castelo Branco. Lisboa: Editorial Caminho, 1988.

FARIA, J. C. José Bonifácio, o moço. São Paulo: Companhia Editora Nacional, 1944.

FAUSTO, B. História do Brasil, São Paulo: Edusp, 1994.

FERREIRA, L. F. Luiz Gama (1830-1882): étude sur la vie et l'xuvre d'un noir citoyen, militant de la lutte anti-esclavagiste au Brésil. Paris, 2001. 4v. Tese (Doutorado) - Universidade de Paris 3 Sorbonne Nouvelle. Paris, 2001.

. Luiz Gama: um abolicionista leitor de Renan. Estudos Avançados, São Paulo, v.20, n.60, p.271-88, 2007.

Luiz Gama por Luiz Gama: carta a Lúcio de Mendonça. Teresa. Revista de Literatura Brasileira, São Paulo, n.8/9, p.300-21, 2008.

FERREIRA, L. F. Luiz Gama, defensor dos escravos e do Direito. In: MOTA, C. G. 
(Org.) Os Juristas na Formação do Estado-Nação Brasileiro. São Paulo: FGV Editora, 2010. v.2, p.219-44.

FERREIRA, L. F. (Org. apres. Notas) Com a palavra Luiz Gama. Poemas, artigos, cartas, máximas. São Paulo: Imprensa Oficial do Estado de São Paulo, 2011.

GAMA, L. Primeiras Trovas Burlescas de Getulino. São Paulo: Typografia Dous de Dezembro de Antonio Louzada Antunes, 1859. 129p.

Primeiras Trovas Burlescas de Getulino. 2.ed. correcta e augmentada. Rio de Janeiro: Typ. de Pinheiro e Cia., 1861. 252p.

Uma carta [de José Bonifácio]. Almanack Litterario de São Paulo para o anno de 1881, publicado por José Maria Lisboa. São Paulo: Tipografia da “Província”, 1880. p.201-5.

. Primeiras Trovas Burlescas er outros poemas de Luiz Gama. Ed., introd. e notas Ligia Fonseca Ferreira. São Paulo: Martins Fontes, 2000. 388p.

Carta a Lúcio de Mendonça, 25 de julho de 1880. In: FERREIRA, L. F. (Org.) Com a palavra Luiz Gama. Poemas, artigos, cartas, máximas. São Paulo: Imprensa Oficial, 201la. p.202.

Pela última vez, Correio Paulistano, 3 de dezembro de 1869. In: FERREIRA,

L. F. (Org.) Com a palavra Luiz Gama. Poemas, artigos, cartas, máximas. São Paulo: Imprensa Oficial, 2011 b.

GENETTE, G. Paratextos editoriais. Trad. Álvaro Faleiros. Cotia: Ateliê Editorial, 2009.

GUIMARÃES, H. Machado de Assis e Faustino Xavier de Novais. In: SENNA, M. de; GUIMARÃES, H. de S. (Org.) Machado de Assis e o outro: diálogos possíveis.. Rio de Janeiro: Móbile, 2012. p.109-22.

HALLEWELL, L. O livro no Brasil: sua história. Trad. Maria da Penha Villalobos, Lólio Lourenço de Oliveira e Geraldo Gerson de Souza. 2.ed. rev. e ampl. São Paulo: Edusp, 2005.

HONOUR, H. L'image du Noir dans l'art occidental. Paris: Gallimard, 1989. t.2., p.24l.

MAHRER, R. La plume après le plomb. Génésis, Paris, n.44, p.17-38, 2017.

MARQUES, P. De ler e ouvir e ouvir poesia: Luiz Gama e Machado de Assis. Machado de Assis em linha, São Paulo, v.11, n.24, p.12-32, agosto 2018.

MENUCCI, S. O precursor do Abolicionismo no Brasil. São Paulo: Companhia Editora Nacional, 1938.

NOVAIS, F. X. Poesias. Segunda edição correcta e augmentada. Porto: Typ. de Sebastião José Pereira, 1856.

Novas Poesias, precedidas de um juizo critico de C. Castello Branco. Porto: Ernesto Chardron, [ $1^{\text {a }}$ edição 1858] 1881.

SAYERS, R. O negro na literatura brasileira. Rio de Janeiro: Edições O Cruzeiro, 1958.

SILVA, J. B. A. Poesias. Org. e apres. Alfredo Bosi e Nilo Scalzo. São Paulo: Conselho

Estadual de Cultura/ Comissão de Literatura, 1962. 
RESUMO - Neste artigo pretende-se, pelo cotejo das duas primeiras edições das Primeiras Trovas Burlescas de Luiz Gama, acompanhar nascimento, formação e evolução de um autor, desde o início envolvido na organização e produção editorial de seus livros. Trata-se, na realidade, de uma obra "dupla”, por trazer ali poemas de José Bonifácio, o moço. Considerando-se que um autoré antes de tudo um leitor, buscaremos identificar, através das epígrafes, as leituras e modelos seguidos pelo novato poeta, em especial a obra do poeta português Faustino Xavier de Novais. Por fim, observaremos as mudanças e as etapas (textuais e não textuais) percorridas de uma edição a outra, buscando nos bastidores paratextuais a presença do autor, leitor e “editor” Luiz Gama.

PALAVRAS-CHAVE: Luiz Gama, Primeiras Trovas Burlescas, Faustino Xavier de Novais, José Bonifácio, o moço, Paratexto editorial.

ABSTRACT - By comparing the first two editions of Luiz Gama's Primeiras Trovas Burlescas [First burlesque troves], we follow the birth, formation and evolution of an author who, from the beginning, was involved in the organization and editorial production of his own books. Actually, it is a "double" work, for it also brings poems of José Bonifácio, the younger. Considering that an author is first and foremost a reader, we will seek to identify, through the epigraphs, the readings and models followed by the novice poet, especially the works of Portuguese poet Faustino Xavier de Novais. Finally, we will follow the changes from one edition to the next and the stages (textual and non-textual) of each one, searching in the paratextual background the manifestation of the author, reader and “editor" Luiz Gama..

KErWords: Luiz Gama, Primeiras Trovas Burlescas, Faustino Xavier de Novais, José Bonifácio the younger, Paratextual editing.

Ligia Fonseca Ferreira é professora associada do Departamento de Letras da Unifesp, com doutorado pela Universidade de Paris 3 - Sorbonne, e pós-doutorado pelo Instituto de Estudos Brasileiros da USP. @ - ligia.ff@uol.com.br https://orcid.org/0000-0002-5305-6521

${ }^{\text {I }}$ Departamento de Letras, Universidade Federal de São Paulo, São Paulo, Brasil.

Recebido em 14.6.2019 e aceito em 10.7.2019. 
Quadro 1 - Epígrafes de Faustino Xavier de Novais em poemas das PTB

\begin{tabular}{|c|c|}
\hline Título & Epígrafes (grafia atualizada) \\
\hline Prólogo / Prótase & $\begin{array}{l}\text { Embora um vate canhoto / Dos loucos aumente a lista, / Seja } \\
\text { Cisne ou gafanhoto, / Não encontra quem resista / Dos seus } \\
\text { versos à leitura / Que diverte, inda que é dura! ("Pretensões", } \\
\text { Novas Poesias, [1858], 1881, p. 20) }\end{array}$ \\
\hline Lá vai verso! & $\begin{array}{l}\text { Quero também ser poeta, / Bem pouco, ou nada me importa, / } \\
\text { Se a minha veia é discreta, / Se a via que sigo é torta. (idem, } \\
\text { p.17) }\end{array}$ \\
\hline $\begin{array}{l}\text { Sortimento de gorras } \\
\text { para gente de grande } \\
\text { tom }\end{array}$ & $\begin{array}{l}\text { Seja um sábio o fabricante, / Seja a fábrica mui rica, / Quem } \\
\text { carapuças fabrica / Sofre um dissabor constante; / Obra } \\
\text { pronta, voa errante, / Feita avulso, e sem medida; / Mas no } \\
\text { vôo suspendida, / Por qualquer que lhe apareça / Lá lhe fica na } \\
\text { cabeça, / Té as orelhas metida. (“As carapuças”, idem, p.49) }\end{array}$ \\
\hline O velho namorado & $\begin{array}{l}\text { Pobre velho! Estás perdido / Se nesse couro tão duro, / Pôde } \\
\text { ainda fazer-te um furo / Uma seta de Cupido! / Desse mal } \\
\text { acometido, / Remédio te não darão; / Que nessa idade a } \\
\text { paixão, / Bem que assim te não pareça, / É moléstia da cabeça, } \\
\text { / Que não sente o coração. ("A um velho namorado", Poesias, } \\
\text { 1856, p.169) }\end{array}$ \\
\hline $\begin{array}{l}\text { No álbum do meu } \\
\text { amigo J. A. Silva } \\
\text { Sobral }\end{array}$ & $\begin{array}{l}\text { Amigo ........ / Pedes um canto na lira, / A quem apenas lhe tira } \\
\text { / Sons de viola chuleira ? / Insistes dessa maneira ? / Não sabes } \\
\text { que, por desgraça, / Por mais esforços que faça / Por ser vate é } \\
\text { sempre em vão? / Não vês que mente o rifão : / Quem porfia } \\
\text { mata caça ? ("No álbum do meu íntimo amigo Carlos Nogueira } \\
\text { Pinto Gandra", idem, p.28) }\end{array}$ \\
\hline $\begin{array}{l}\text { A guarda nacional } \\
\text { (1859) }\end{array}$ & $\begin{array}{l}\text { Desgraçado d'aquele .../ Que em galardão só tem o desabafo./ } \\
\text { De talhar sem medida, carapuças. /Mandal-as por ahi buscar } \\
\text { cabeças!/Se alguma te servir, ou aos amigos/ Que lá, de longe } \\
\text { a longe te aparecem,/ Podes d'elas dispor, que imensas ficam/ } \\
\text { Na fábrica onde tem muitas nascido,/ Que dispersas voando, ao } \\
\text { som do vento, / Nenhuma sem cabeça tem ficado. ("Epístola", } \\
\text { Poesias, p.168) }\end{array}$ \\
\hline
\end{tabular}




\begin{tabular}{|l|l|}
\hline $\begin{array}{l}\text { A um vate } \\
\text { enciclopédico }\end{array}$ & $\begin{array}{l}\text { Quis um jovem marchar, só por mania, / Das letras pela senda } \\
\text { trabalhosa; / Diz-se Vate - mas prenda tão famosa / Ninguém } \\
\text { nos versos seus a descobria. / Começa a dar patada, e tão bravia, } \\
\text { / Que logo (alçando a voz imperiosa) / Lhe brada a natureza } \\
\text { : Chega à prosa ! / E o maldito a encostar-se à poesia ! "A um } \\
\text { aspirante a poeta", idem, p.89) }\end{array}$ \\
\hline $\begin{array}{l}\text { No álbum do Sr } \\
\text { Capitão João Soares }\end{array}$ & $\begin{array}{l}\text { Escrever num Álbum ! ... Credo ! / Expor-me à crítica austera! } \\
\text { / E se um douto me impusera / Pena de longe degrêdo ! / } \\
\text { ponha o meu nome a par / Dos que têm estro e ciência: / } \\
\text { Amigo tem paciência : / Quem não tem não pode dar. ("No } \\
\text { álbum do meu íntimo amigo Carlos Nogueira Pinto Gandra", } \\
\text { idem, p.28) }\end{array}$ \\
\hline $\begin{array}{l}\text { O Barão da } \\
\text { Borracheira }\end{array}$ & $\begin{array}{l}\text { Quando pilho um desses nobres, / Ricos só d'áureo metal } \\
\text { / Mas d'espírito tão pobres / Que não possuem real, / Não } \\
\text { lhes saio do costado / - Sei que é trabalho badalo, / Porque a } \\
\text { pele dura tem; / Mas eu fico satisfeita, / Que o meu ferrão só } \\
\text { respeita / A virtude, e mais ninguém! “A vespa”, Novas Poesias, } \\
\text { p.96-7). }\end{array}$ \\
\hline $\begin{array}{l}\text { govo sortimento de para gente de } \\
\text { grande tom }\end{array}$ & $\begin{array}{l}\text { De repente, magoado / Da carapuça maldita, / Qual possesso, } \\
\text { artista, coitado, / Já de receio convulso / Quer provar que } \\
\text { nobre impulso / O move, quando trabalha ! / _ A carapuça que } \\
\text { talha / Ninguém crê ser feita avulso ! “As carapuças", idem, } \\
\text { p.49-50) }\end{array}$ \\
\hline
\end{tabular}




\begin{tabular}{|c|c|c|}
\hline Título & 1859 & 1861 \\
\hline Prótase (1.ed.)/ Prólogo (2.ed.) & $\mathrm{x}$ & $\mathrm{x}$ \\
\hline Lá vai verso! & $\mathrm{x}$ & $\mathrm{x}$ \\
\hline Junto à estátua & $\mathrm{x}$ & $\mathrm{x}$ \\
\hline Sortimento de gorras para a gente do grande tom & $\mathrm{x}$ & $\mathrm{X}$ \\
\hline $\mathrm{O}$ velho namorado & & $\mathrm{x}$ \\
\hline $\begin{array}{l}\text { N'um álbum (la ed.) / No álbum do meu amigo } \\
\text { J. A. Silva Sobral (2.ed.) }\end{array}$ & $\mathrm{x}$ & $\mathrm{x}$ \\
\hline Caricatura (1.ed.) / O Gamenho (2.ed.) & $\mathrm{x}$ & $\mathrm{x}$ \\
\hline Soneto & & $\mathrm{X}$ \\
\hline Soneto (A uma fabricante de pílulas ) & & $\mathrm{X}$ \\
\hline Soneto (Ao mesmo) & & $\mathrm{X}$ \\
\hline Arreda que lá vai um vate & $\mathrm{x}$ & $\mathrm{X}$ \\
\hline A pitada & & $\mathrm{x}$ \\
\hline O Balão & & $\mathrm{X}$ \\
\hline A um fabricante de pírulas & & $\mathrm{X}$ \\
\hline A um nariz & & $\mathrm{X}$ \\
\hline Uma orquestra & & $\mathrm{x}$ \\
\hline $\begin{array}{l}\text { O grande curador do mal das } \\
\text { Vinhas }\end{array}$ & $\mathrm{x}$ & $\mathrm{x}$ \\
\hline Pacotilha & $\mathrm{x}$ & $\mathrm{x}$ \\
\hline Coleirinho & & $\mathrm{x}$ \\
\hline Soneto (retrato) & & $\mathrm{x}$ \\
\hline A um vate enciclopédico & $\mathrm{x}$ & $\mathrm{X}$ \\
\hline $\begin{array}{l}\text { No álbum do Sr. Capitão João } \\
\text { Soares }\end{array}$ & $\mathrm{x}$ & $\mathrm{x}$ \\
\hline A uns colarinhos & $\mathrm{x}$ & $\mathrm{X}$ \\
\hline Serei conde, marquês e deputado & $\mathrm{x}$ & $\mathrm{x}$ \\
\hline Os glutões & $\mathrm{x}$ & $\mathrm{x}$ \\
\hline Farmacopéia & $\mathrm{x}$ & $\mathrm{x}$ \\
\hline A borboleta & & $\mathrm{x}$ \\
\hline Quem sou eu? & & $\mathrm{X}$ \\
\hline O janota & & $\mathrm{X}$ \\
\hline Laura & & $\mathrm{X}$ \\
\hline Que mundo é este? & $\mathrm{x}$ & $\mathrm{x}$ \\
\hline O barão de Borracheira & $\mathrm{x}$ & $\mathrm{x}$ \\
\hline A cativa & & $\mathrm{X}$ \\
\hline Soneto & & $\mathrm{X}$ \\
\hline $\begin{array}{l}\text { Novo sortimento de gorras para a } \\
\text { gente do grande tom }\end{array}$ & $\mathrm{x}$ & $\mathrm{x}$ \\
\hline Retrato de um sabichão & & $\mathrm{X}$ \\
\hline Num álbum (É mania) & & $\mathrm{X}$ \\
\hline Minha mãe & & $\mathrm{x}$ \\
\hline No cemitério de São Benedito & $\mathrm{x}$ & $\mathrm{x}$ \\
\hline A guarda nacional & $\mathrm{x}$ & \\
\hline $\begin{array}{l}\text { Carta do Vate Muriçoca ao seu prezado amigo } \\
\text { Zebedeu }\end{array}$ & $\mathrm{x}$ & \\
\hline O fósforo & $\mathrm{x}$ & \\
\hline
\end{tabular}


